\begin{abstract}
No. 4139 February 26, 1949
Bird-Ringing in South Afica

THF first ringing of Soutufrican migratory birds was made eaply ol cember 1948 when the Cape Bird Club, of er the direction of Dr. G. J. Broekhuy. sen efthe University of Cape Town, used specially design ed riets to catch European waders on the mud flats Muizenberg, and marked them with leg bands inscribed "Zoo-Pretoria". The ringing seheme is sponsored by the South African Ornithological Society and is being extended over the Western Province. The birds caught were weighed before marking and release. Little stints, avocets, Sandwich terns, curlew-sandpipers, stilts and other familiar British birds-of-passage and nesting birds are expected to figure prominently in the South African experiment, which will not only elucidate further details about the winter quarters of European waders, and shore birds, but also determine whether many of the birds found at the Cape remain in the Union throughout the year, or nest elsewhere in Africa. Certain species like the black-winged stilt not only migrate from European nesting haunts but also breed in parts of Africa.
\end{abstract}

For many years now migratory birds ringed in European nesting haunts have been recovered at winter haunts in Africa. Notable among these have been the European swallow, the house-martin, the common swift, the cuckoo, the nightjar, the red. backed shrike and the Sandwich tern and the white stork. More thain a score of common swallows markad when nesting or as nestlings in the British Isles have been recovered in South Africa, and the Sandwich tern from Britain has been recovered in Natal.

\section{Research at the University of Sydney}

A commites app intes by the vice-chancellor has prepared an interes ing description of the original scientific wo lane at the University of Sydney during the rears 944 and 1945 , so continuing the account set out on the previous publication for the years 1943-43. The report shows that, despite the absence of many members of staff on war service and the greater amount of teaching duties undertaken by those who remained at the University, much valuable work was carried out and a considerable number of young workers were trained to undertake research. Subjects of research are listed under the headings : art, law, medicine, science, engineering, veterinary science, agriculture, economics and social studies.

\section{University of Leeds}

THE Council of the University of Leeds has announced the receipt of the following gifts, among others: a sum of $£ 200$ given to Prof. S. Brodetsky by his fyends on his retirement from the chair of applied mathematics and presented by him to the Uniy rsity for the establishment of a prize in mathematics; $£ 1,500$ given to the Inorganic and Physical Chemistry Department by the Royal Society for the development of a special Weissenberg goniometer.

The following appointments have been made: Dr. D. G. Christopherson, fellow and bursar of Magdalene College, Cambridge, to be professor of mechanical engineering from September 1, 1949, in succession to the late Prof. W. T. David; Mr. R. Holliday, to be senior lecturer in agriculture.

\section{Royal Society Lectures for 1949}

THE Croonin Lecture for 1949 will be delivered on June 30 by Dr. D. W. Bronk, foreign secretary of the Nahonal Academy of Sciences and chairman of the National Research Council of the United States. As director of the Johnson Institute for Medical Physics in the University of Pennsylvania, he has greatly influenced the development of biophysics, his special field of work being the physiology of the nervous system; his recent work has been on the oxygen consumption of the brain. The Croonian Lecture was founded by Dr. William Croone, one of the original fellows of the Royal Society, "for a lecture and illustrative experiment for the advancement of natural knowledge on local motion" ; the first lecture was delivered in 1738.

The Bakerian Lecture for 1949 will be delivered on Miay 12 by Prof. H. Raistrick, professor of biochemistry in the University of London. This Lecture was founded by Mr. Henry Baker, "for a yearly oration or discourse by one of the Fellows on some part of natural history or experimental philosophy" ; the first lecture was delivered in 1775 .

The Wilkins Lecture for 1949 will be delivered on December 15 by Prof. E. N. da C. Andrade, Quain professor of physics in the University of London. The Wilkins Lecture on the history of science was founded in 1947 by Mr. J. D. Griffith Davies, a recent assistant secretary of the Society, who delivered the first lecture entitled "John Wilkins and the Royal Society" in 1948.

\section{Goethe Bicentenary Lectures}

A SERIES of six cestival lectures in commemoration of the bicenten ry of the birth of Goethe will be held at Universit College, London, under the auspices of the Britich Goethe Festival Society, beginning on March \%. The first lecture is by Prof. L. A. Willoughby, on "che Living Goethe". The remaining lectures are by Dr. G. P. Gooch, on "Goethe, the Liberal-Conservative" (March 10) ; Prof. F. Blume, "Goethe and Music" (March 17); Dr. Karl Wollf, speaking in German, on Goethe's religion (April 21) ; Prof. H. Friedmann, "Goethe's Morphology" (April 28) ; Mr. L. L. Whyte, "Goethe's Single View of Nature and Man" (May 5). The lectures are at 5.30 p.m. and are open to the public without fee or ticket.

\section{First International Congress of Biochemistry}

THE First International Congress of Biochemistry will be held in Combridge during August 19-25, 1949. The Congress/s under the presidency of Prof. A. C. Chibnall, gid for the reading of papers and for discussig it is organised into twelve separate sections, each with its own chairman, as follows : aninal nutrition and general metabolism, Sir Jack Drammond ; microbiological chemistry (vacant through the recent death of Miss Marjory Stephenson); enzymes and tissue metabolism, Prof. R. A. Peters; proteins, Dr. K. Bailey; clinical biochemistry, Prof. E. J. King ; structure and synthesis of biologically important substances, Prof. A. R. Todd ; cytochemistry, Prof. J. N. Davidson; biclogical pigments: oxygen carriers and oxidizing catalysts, Prof. D. Keilin; hormones and steroids, Prof. F. G. Young; chemotherapy and immunochemistry, Sir Charles Harington; plant biochemistry, Dr. C. S. Hanes ; industrial fermentations, Mr. H. J. Bunker. In addition to the meetings of the sections, there will be Congress lectures and visits to research stations and laboratories. The fee for membership of this Congress is $£ 2$. Applications and inquiries should be addressed to the Honorary Organiser, First International Congress of Biochemistry, 56 Victoria Street, London, S.W.1. 